\title{
Mercenaria mercenaria introductions into Florida, USA, waters: duration, not size of introduction, influences genetic outcomes
}

\author{
William S. Arnold*, Stephen P. Geiger, Sarah Peters Stephenson
}

Florida Fish and Wildlife Conservation Commission, Fish and Wildlife Research Institute, 100 Eighth Avenue SE, St. Petersburg, Florida 33701-5020, USA

\begin{abstract}
Wild stocks of hard clams from the genus Mercenaria historically supported commercial fisheries, but, as these stocks have been depleted, market demand has been filled by clams produced in aquaculture operations. Along the east coast of the USA, M. mercenaria is indigenous and used for aquaculture. Indigenous Gulf of Mexico (GOM) clam populations consist of M. campechiensis, a species less suited to aquaculture because of its short shelf life. Aquaculture operations have introduced M. mercenaria into GOM waters, resulting in altered Mercenaria species composition to the detriment of $M$. campechiensis. Where $M$. mercenaria have been introduced, the population now includes both $M$. mercenaria and $M$. campechiensis, and hybrids are common. This is particularly evident where commercial aquaculture is ongoing and introductions are, therefore, continuous. Where shortterm introductions have occurred for research purposes, M. mercenaria is restricted to oyster reefs. At those sites, and at sites where no documented introductions of $M$. mercenaria have occurred, hybrids are rare and $M$. campechiensis dominate the more common sand/seagrass habitats. As the 2 species continue to interbreed, pure $M$. campechiensis will become rarer and hybrids more common, potentially resulting in reduced fitness of $M$. campechiensis from GOM waters. The trend towards hybrids may be ameliorated by an increased intensity of gonadal neoplasia in the hybrid clams. These results indicate that $M$. mercenaria introductions into the GOM, even on the relatively small scale of scientific research efforts, have a substantial and long-lasting influence on the genotype composition of hard clam populations in GOM waters.
\end{abstract}

KEY WORDS: Aquaculture - Introduction - Hard clam - Hybrid - Introgression - Mercenaria · Population genetics $\cdot$ Neoplasia

\section{INTRODUCTION}

Hard clams of the genus Mercenaria have an extensive cultural and economic history in Atlantic and Gulf of Mexico (GOM) waters of the eastern USA. Even prior to European colonization of North America, native Americans harvested hard clams for food, to serve as tools, and as a form of money (Quitmyer \& Jones 1992), and it appears that the colonists learned the value and utility of hard clams from their native American hosts (MacKenzie et al. 2001). However, it was not until the late 1800 s, when transportation and preservation techniques were developed, that the har- vest of hard clams for commercial sale became feasible and commonplace. As with so many fisheries, commercial exploitation combined with habitat loss and pollution have resulted in a considerable decrease in the availability of hard clams, as reflected by commercial landings records (www.st.nmfs.noaa.gov/pls/webpls/ MF_ANNUAL_LANDINGS.RESULTS). In response to this decrease in the availability of wild hard clams for harvest and consumption, techniques have been developed for their cultivation. Culture techniques were originally developed in the northeastern USA by such icons as Wells, Loosanoff, and Glancy (Castagna 2001). As those techniques became available to more 
users, hard clam aquaculture spread to many areas throughout the eastern seaboard of the USA and eventually to the GOM.

Although culture techniques were well developed by the 1950s, field growout of the hatchery-reared clams remained problematic. Field growout is a necessary component of an economically viable clam aquaculture operation (Castagna \& Kraeuter 1977), but planting juvenile and even adult clams in the field without some form of predator protection results in unacceptable losses (Arnold 1984, Marelli \& Arnold 1990, Arnold et al. 2002). Considerable effort has been devoted to the development of field growout strategies designed to reduce mortality, particularly due to predation, to acceptable levels. This work was pioneered in Florida waters during the late 1950s and early 1960s by Winston Menzel and colleagues (Castagna 2001), who used caged boxes or fences to protect the seed clams they planted in Alligator Harbor in northwestern Florida (Fig. 1; Menzel 1961, Menzel \& Sims 1962). Menzel's focus was on the feasibility of developing hard clam aquaculture in the northern GOM and the relative efficacy of the 2 species of hard clam Mercenaria mercenaria and $M$. campechiensis and their various hybrid forms for that purpose. However, only $M$. campechiensis is native to GOM coastal waters (Menzel 1968, Dillon \& Manzi 1989a, Harte 2001, Baker et al. 2008). Although Menzel $(1968,1969)$ suggested that a subspecies (M. m. texana) did occur in northern GOM waters, genetic analyses refuted that and instead classified texana as a subspecies of $M$. campechiensis (Dillon \& Manzi 1989b). Thus, Menzel's use of M. mercenaria in his northern GOM studies actually constituted an introduction of this species into that sea.

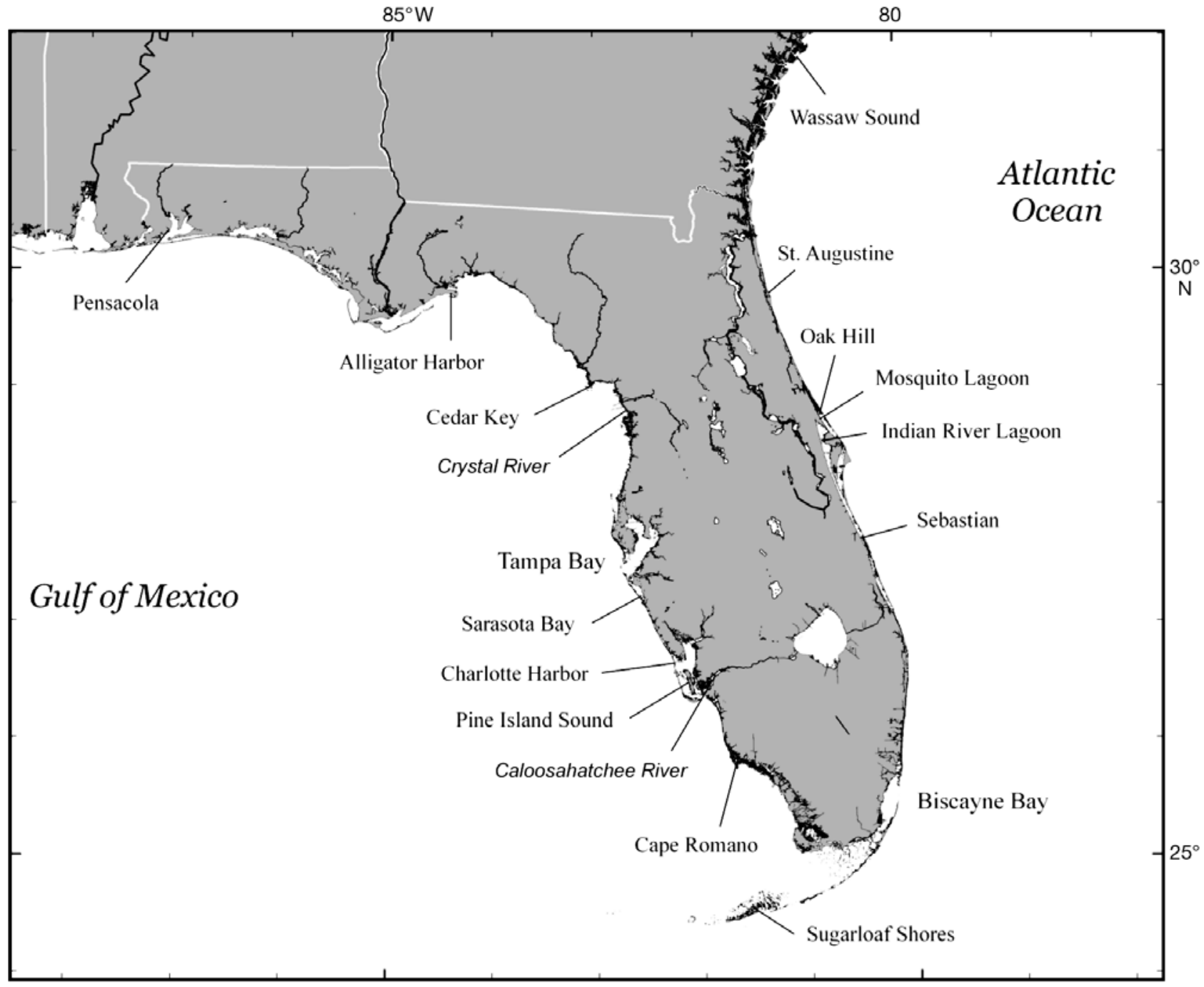

Fig. 1. Sampling locations in Georgia and along the east and west coasts of Florida, USA. The Cedar Key collection was obtained from a commercial hard clam Mercenaria spp. aquaculture lease site. All other samples were collected from the resident wild population 
In 1960, M. mercenaria and $M$. mercenaria $\times M$. campechiensis seed clams cultured at the Milford, Connecticut, laboratory of the US Fish and Wildlife Service were shipped to Florida and planted at various sites throughout the state (Woodburn 1961). East coast planting sites included Mosquito Lagoon near Oak Hill, the Indian River Lagoon near Sebastian, and Biscayne Bay. West coast planting sites included Sugarloaf Shores in the Florida Keys, Sarasota Bay, Tampa Bay, Crystal River, and Alligator Harbor (Fig. 1). Approximately 600 M. mercenaria and $2000 \mathrm{~F}_{1}$ hybrid clams were planted at each site. Success varied from site to site, but clams appear to have survived to maturity at all but perhaps the Biscayne Bay site (Woodburn 1961).

More recently, large numbers of Mercenaria mercenaria have been transplanted into the Floridian GOM to support commercial aquaculture operations (Colson \& Sturmer 2000). Those efforts began in the Cedar Key region in 1993 (Colson \& Sturmer 2000) and were then expanded to include sites in Charlotte Harbor on an experimental basis in 1994 and as a fully commercial operation in 1996, to Pine Island Sound in 1997, to Alligator Harbor in 2004, and to the Cape Romano region in 2006 (Fig. 1). In all cases, M. mercenaria was the species of choice because of its longer shelf life relative to its congener (Menzel 1989, Arnold et al. 2004). Thus, the spread of $M$. mercenaria alleles into the eastern GOM hard clam population, previously described for the Cedar Key region by Arnold et al. (2004), continues unabated.

The goal of the present study was to assess the genotype composition of hard clam stocks along both the eastern and western coasts of Florida, to date any changes in genotype composition using standard sclerochronological techniques, and to evaluate the relative contribution (if any) of scientific studies versus aquaculture operations to observed changes in genotype composition of hard clams, particularly along the GOM coast of the state. We also evaluated gonadal neoplasia (Hesselman et al. 1988) in the various hard clam populations to determine if the frequency or intensity of this debilitating disease is greater in clam populations exposed to introductions of nonindigenous Mercenaria mercenaria than in unexposed populations (Bert et al. 1993). Finally, we assessed the frequency of occurrence of the 'notata' phenotypic marker (Chanley 1961, Humphrey \& Walker 1982) in each of the sampled clam populations. This marker is rare in wild hard clams, but has been preferentially bred into commercially cultured clams to identify ownership of those clams following outplant. Its frequency of occurrence in wild hard clams, exposed to cultured clams in a field setting, thereby provides a secondary estimate of the introduction of alleles from the cultured to the wild population.

\section{MATERIALS AND METHODS}

Field collections. Live clams were collected from Florida's Atlantic and GOM coastal waters (Table 1) and at one site in Wassaw Sound, Georgia. Most clams were collected by hand, although in a few instances (e.g. Mosquito Lagoon) the clams were collected using commercial clam rakes. Clams were returned to the laboratory within $1 \mathrm{~d}$ of collection and were dissected as detailed below within $2 \mathrm{~d}$ of return to the laboratory.

We based our site selection on several criteria, including the location of each site relative to the others chosen (to ensure representative coverage), and the history of clam introductions at each site (Table 2). We chose Wassaw Sound, St. Augustine, Mosquito Lagoon, and Sebastian as representative east coast sites, the latter 3 of which had experienced documented Mercenaria mercenaria introductions at some time in their recent history. Wassaw Sound was chosen as an east coast outlier, with no documentation of $M$. mercenaria introduction. We chose Cape Romano, Charlotte Harbor, and Pensacola Bay as representative west coast sites with no history of successful $M$. mercenaria introductions. Commercial $M$. mercenaria aquaculture was introduced into Charlotte Harbor in 1994, with an expected initial genetic impact beginning in 1995 (Arnold et al. 2004), but few of the clams we collected from that site were hatched after the introduction of aquaculture so we consider this to be an unaffected site for the purposes of the present study. Each of the remaining west coast sites - including Pine Island Sound, Sarasota Bay, Tampa Bay Sand Flat, Tampa Bay Oyster Reef, and Alligator Harbor-had experienced M. mercenaria introduction at some time since 1958.

Laboratory methods. Clams were processed to provide tissue for genetic and disease analyses and to provide shells for ageing analyses. The shell of each specimen was carefully opened to prevent damage, and the adductor muscles were then severed to allow full opening of the valves. Samples of gill, mantle, and adductor muscle tissue were excised and placed in plastic wrap; the samples were then wrapped in aluminum foil and placed in an ultracold freezer $\left(-80^{\circ} \mathrm{C}\right)$ to await allozyme electrophoretic analysis. The remaining visceral mass was then fixed according to the methods described below, in anticipation of histological preparation. Finally, the shell of each specimen was cleaned and labeled for annual growth increment analysis.

Genetic analyses: To classify the 2 pure species and their hybrid forms, samples of combined muscle, mantle, and gill tissue were assayed for 4 semi-diagnostic (sensu Bert \& Arnold 1995) enzyme loci using starch gel electrophoresis (Bert et al. 1993). The 4 enzymes included glucose phosphate isomerase (GPI), 
Table 1. Mercenaria spp. Collection information for hard clams from each site; shell-height parameters calculated for the pooled sample. Letters under 'Tukey grouping' indicate significantly different mean shell heights

\begin{tabular}{|c|c|c|c|c|c|c|c|c|}
\hline \multirow[t]{2}{*}{ Location } & \multirow[t]{2}{*}{ Habitat type } & \multirow{2}{*}{$\begin{array}{l}\text { Sample } \\
(\mathrm{N})\end{array}$} & \multirow{2}{*}{$\begin{array}{l}\text { Collection } \\
\text { date }\end{array}$} & \multicolumn{4}{|c|}{ Shell height (mm) } & \multirow{2}{*}{$\begin{array}{l}\text { Tukey } \\
\text { grouping }\end{array}$} \\
\hline & & & & Mean & $\mathrm{SD}$ & Min. & Max. & \\
\hline \multirow[t]{3}{*}{ Charlotte Harbor } & \multirow{3}{*}{$\begin{array}{l}\text { Subtidal sand/mud in } \\
\text { vicinity of clam leases; } \\
\text { unvegetated }\end{array}$} & 23 & 14 Apr 2003 & \multirow[t]{3}{*}{105.3} & \multirow[t]{3}{*}{8.9} & \multirow[t]{3}{*}{85.9} & \multirow[t]{3}{*}{122.8} & \multirow[t]{3}{*}{$\mathrm{a}$} \\
\hline & & 12 & 3 Jun 2003 & & & & & \\
\hline & & 13 & 25 Aug 2003 & & & & & \\
\hline \multirow{4}{*}{$\begin{array}{l}\text { Tampa Bay } \\
\text { Sand Flat }\end{array}$} & \multirow{4}{*}{$\begin{array}{l}\text { Intertidal/shallow subtidal } \\
\text { sand flat; Thalassia }\end{array}$} & 9 & 9 Jul 2003 & \multirow[t]{4}{*}{103.6} & \multirow[t]{4}{*}{19.7} & \multirow[t]{4}{*}{49.7} & \multirow[t]{4}{*}{141.6} & \multirow[t]{4}{*}{$\mathrm{a}$} \\
\hline & & 3 & $10 \mathrm{Jul} 2003$ & & & & & \\
\hline & & 23 & $18 \mathrm{Jul} 2003$ & & & & & \\
\hline & & 19 & 14 Aug 2003 & & & & & \\
\hline Sarasota Bay & Subtidal sand; Thalassia & 51 & 31 Oct 2003 & 79.8 & 14.0 & 24.5 & 103.4 & $\mathrm{~b}$ \\
\hline $\begin{array}{l}\text { Pine Island } \\
\text { Sound }\end{array}$ & $\begin{array}{l}\text { Intertidal/shallow subtidal } \\
\text { sand flat; unvegetated }\end{array}$ & 49 & 5 Aug 2003 & 77.1 & 26.5 & 37.3 & 116.6 & $\mathrm{~b}$ \\
\hline Sebastian & $\begin{array}{l}\text { Subtidal sand/mud habitat; } \\
\text { unvegetated }\end{array}$ & 51 & 11 Dec 2003 & 74.8 & 7.6 & 56.4 & 87.5 & $\mathrm{~b}, \mathrm{c}$ \\
\hline \multirow{2}{*}{$\begin{array}{l}\text { Tampa Bay } \\
\text { Oyster Reef }\end{array}$} & \multirow[t]{2}{*}{ Intertidal oyster reef } & 40 & 15 May 2003 & \multirow[t]{2}{*}{74.5} & \multirow[t]{2}{*}{10.7} & \multirow[t]{2}{*}{48.1} & \multirow[t]{2}{*}{91.7} & \multirow[t]{2}{*}{$\mathrm{b}, \mathrm{c}$} \\
\hline & & 10 & 29 May 2003 & & & & & \\
\hline Pensacola Bay & Subtidal soft sand; Thalassia & 49 & 24 Oct 2003 & 70.9 & 11.0 & 34.5 & 106.4 & $\mathrm{~b}, \mathrm{c}, \mathrm{d}$ \\
\hline \multirow[t]{5}{*}{ Cape Romano } & Subtidal sand/mud/clay & 3 & $30 \mathrm{Jul} 2002$ & \multirow[t]{5}{*}{70.9} & \multirow[t]{5}{*}{30.5} & \multirow[t]{5}{*}{34.3} & \multirow[t]{5}{*}{127.8} & $\mathrm{~b}, \mathrm{c}, \mathrm{d}$ \\
\hline & habitats; unvegetated & 3 & 5 Aug 2002 & & & & & \\
\hline & & 4 & 1-2 Sep 2002 & & & & & \\
\hline & & 8 & 6 Sep 2002 & & & & & \\
\hline & & 3 & 8 Oct 2002 & & & & & \\
\hline Alligator Harbor & Intertidal oyster reef & 16 & 14 Nov 2002 & 69.7 & 15.8 & 38.3 & 95.5 & $\mathrm{~b}, \mathrm{c}, \mathrm{d}$ \\
\hline & & 4 & 25 Nov 2003 & & & & & \\
\hline St. Augustine & $\begin{array}{l}\text { Tidal creek, sandy mud; } \\
\text { unvegetated }\end{array}$ & 51 & 15 May 2003 & 65.2 & 16.3 & 27.0 & 93.3 & $\mathrm{c}, \mathrm{d}$ \\
\hline Mosquito Lagoon & $\begin{array}{l}\text { Subtidal sand/shell habitat; } \\
\text { unvegetated }\end{array}$ & 81 & 6 Aug 2002 & 61.6 & 18.4 & 26.1 & 111.9 & $\mathrm{~d}$ \\
\hline Wassaw Sound & $\begin{array}{l}\text { Intertidal creek, shelly } \\
\text { sand/mud, unvegetated }\end{array}$ & 60 & 6 Jul 2003 & 48.3 & 15.5 & 23.0 & 84.9 & e \\
\hline $\begin{array}{l}\text { Cedar Key } \\
\text { Aquaculture }\end{array}$ & $\begin{array}{l}\text { Field deployed growout } \\
\text { bags; unvegetated }\end{array}$ & 87 & 22 Jan 2003 & 47.6 & 5.0 & 35.9 & 57.3 & e \\
\hline
\end{tabular}

Table 2. Mercenaria mercenaria. History of introductions at the various study sites throughout Florida, including the year during which first introductions were recorded. Introductions are differentiated between large-scale introductions for the purpose of commercial aquaculture and small-scale introductions for the purpose of investigating aquaculture potential (Science)

\begin{tabular}{|lcll|}
\hline Site & Aquaculture & Science & Comments \\
\hline Wassaw Sound & None & None & Aquaculture introductions post-sampling \\
St. Augustine & 1993 & None & $2-3$ leases extant in 2007 \\
Mosquito Lagoon & 1997 & 1960 & Aquaculture discontinued \\
Sebastian & 1978 & 1960 & Large-scale aquaculture continues \\
Cape Romano & 2005 & None & Aquaculture introductions post-sampling \\
Pine Island Sound & 1997 & None & Large-scale aquaculture (hurricane impacts) \\
Charlotte Harbor & 1994 & None & Approximately 5 leases \\
Sarasota Bay & None & 1960 & Test plots deployed post-sampling \\
Tampa Bay Sand Flat & None & 1960 & No history of aquaculture \\
Tampa Bay Oyster Reef & None & 1960 & No history of aquaculture \\
Alligator Harbor & None & 1958 & Aquaculture introductions post-sampling \\
Pensacola Bay & None & None & No history of aquaculture \\
\hline
\end{tabular}


phenylalanine-specific dipeptidase-2 (DPEP2), aspartate aminotransferase (AAT), and phosphoglucomutase-2 (PGM2), each of which displays significant and pronounced differences in allele frequency between the 2 species (Bert \& Arnold 1995). The only procedural modification from Bert et al. (1993) involved the use of both Gel/Electrode Buffer System 2 and Gel/Electrode Buffer System 3 for DPEP2 and PGM2 (Selander et al. 1971, Bert 1986). Gel/Electrode Buffer System 5 remained the only system used for GPI and AAT (Bert 1986).

Each individual was classified as Mercenaria mercenaria, M. campechiensis, or hybrid following the procedures of Bert et al. (1993) and Bert \& Arnold (1995). For each locus, each allele was assigned a numerical allele diagnostic value (ADV), calculated as $f_{\mathrm{m}}-f_{\mathrm{c}}$, where $f_{\mathrm{m}}$ is the mean frequency of the allele in $M$. mercenaria and $f_{\mathrm{c}}$ is the mean frequency of the allele in $M$. campechiensis. The putative pure-species M. campechiensis were collected from Texas and northwest Florida (Cedar Key and St. Joseph Bay), whereas the putative pure-species $M$. mercenaria were collected from Connecticut, North Carolina, and the east coast of Florida (Matanzas Inlet, Ft. Pierce) (Bert \& Arnold 1995). All putative pure-species collections of $M$. campechiensis were made prior to any documented introductions of $M$. mercenaria at the collection site.

Following Bert et al. (1993), for each individual, a genetic-index score for each locus was calculated as the sum of the 2 ADVs for the locus. The 4 geneticindex scores for each individual from the various Florida populations (including Wassaw Sound, Georgia) and for each individual from the pure-species samples were then entered as response variables into a standard discriminant-function analysis (DFA) in which pure-species individuals were used to define the range of genetic-index scores for each species, the hybrid range was defined as the range of scores between the 2 species' score ranges, and the individuals from the various Florida populations were entered as unknowns. For each individual, the DFA calculated the probability that the individual was a member of each of the 3 genotype classes (Mercenaria mercenaria, $M$. campechiensis, hybrid). Each individual was assigned to the genotype class to which it had the highest posterior probability of belonging. Because not all loci could be resolved for all individuals, the DFA was repeated using two 3-locus combinations (DPEP2, GPI, AAT; DPEP2, GPI, PGM2) and the 2-locus combination with the greatest difference in allele frequencies between the 2 species (DPEP2, GPI) to maximize the number of individuals classified.

Our 7 pure-species samples were chosen by performing principal components analysis (PCA) using the correlation matrix of the diagnostic-locus geneticindex scores of 20 samples collected from throughout the combined ranges of the 2 species in the USA. Thus, as recommended by Neff \& Smith (1978), PCA was used to identify the groups of populations suitable for use as defined species samples. The DFA, which is useful in allocating new observations to defined groups (James \& McCulloch 1990), was then an appropriate method for assigning individuals from the various Florida populations to genotype classes.

Neoplasia assessment: To assess the frequency of neoplasia, each clam gonad was removed during the dissection process and stored in a solution of $10 \%$ buffered formalin for $24 \mathrm{~h}$. After an initial $4 \mathrm{~h}$ of submersion, large gonads were removed from the fixative, lacerated along the longitudinal axis to ensure complete penetration of fixative, and returned to the solution for the remaining $20 \mathrm{~h}$. Excess fixative was then removed by thoroughly rinsing each gonad in tap water. The gonads were dehydrated through a series of alcohol concentrations (70 to $100 \%$ ) and treated with xylene before being embedded in Paraplast paraffin. Two $3.0 \mu \mathrm{m}$ sections, separated by 10 to $15 \mu \mathrm{m}$, were then cut from each embedded gonad using a ThermoShandon Finesse 325 microtome equipped with a TissueTek Accu-Edge disposable microtome blade. The resultant sections were mounted on glass slides, stained with hematoxylin and eosin by using a Leica Autostainer XL, and then covered and stored for later microscopic analysis.

Gonad sections were examined under a compound microscope at 100 to $400 \times$ magnification to identify gender and to determine if neoplastic cells were present in the gonad (Hesselman et al. 1988, Bert et al. 1993). When neoplasia was determined to be present, the progression of the disease was classified as being in 1 of 6 stages, as summarized in Table 3 (Arnold et al. 2004). Note that Stage 1 does not constitute true neoplasia according to Cotran et al. (1999), because neoplasia are characterized as multiple rather than single cells. Therefore, although the individual cells that characterize Stage 1 of the progression appear morphologically identical to the cells that constitute later stages, Stage 1 and 0 individuals were considered to be non-neoplastic. Stages 1.5 to 4 always involved clumps of 2 or more similar and clearly aberrant cells.

Age determination: One valve from each specimen was radially sectioned from the umbo to the ventral margin along the axis of maximum shell height by using a Lortone Model FS lapidary trim saw equipped with a Raytech $20 \mathrm{~cm}$ diameter diamond blade. Each clam was aged according to standard techniques (Quitmyer et al. 1997). An annual growth increment consisted of 1 opaque and 1 translucent growth incre- 
Table 3. Mercenaria spp. Criteria for staging gonadal neoplasia (percentage of gonadal follicles containing neoplastic cells) in hard clams from Florida in 2002 and 2003. Criteria modified from Hesselman et al. (1988), Bert et al. (1993)

\begin{tabular}{|c|c|c|}
\hline Stage & Extent $(\%)$ & Description \\
\hline 0 & 0 & No neoplasia detected \\
\hline 1 & $<10$ & $\begin{array}{l}\text { Single cells, morphologically similar to } \\
\text { cells contained within neoplastic clusters } \\
\text { but failing the definition for neoplasia }\end{array}$ \\
\hline 1.5 & $<10$ & $\begin{array}{l}\text { Small foci of neoplastic cells originate } \\
\text { from germinal epithelium }\end{array}$ \\
\hline 2 & $10-75$ & $\begin{array}{l}\text { Neoplastic cells occupy lumen of } \\
\text { several follicles }\end{array}$ \\
\hline 3 & $>75$ & $\begin{array}{l}\text { Neoplastic cells occupy nearly all } \\
\text { germinal follicles but have not dis- } \\
\text { seminated germinal tissue }\end{array}$ \\
\hline 4 & $75-100$ & $\begin{array}{l}\text { Neoplastic cells have invaded } \\
\text { surrounding tissues }\end{array}$ \\
\hline
\end{tabular}

ment; the ventral margin of each translucent growth increment defined the end of an annual cycle (Arnold et al. 1991). We counted growth increments to determine the age (in years) of the clam. The seasonal timing of formation of the annual growth increments is similar for the 2 Mercenaria species and their hybrid forms (Arnold et al. 1998).

If the age was difficult to determine from the original cut-for example, because the bands in the ventral margin were densely concentrated-the shell was polished with a succession of emery paper grades. If, following polishing, the number of bands remained ambiguous, an acetate-peel technique was employed (Kennish et al. 1980). The resulting peel was mounted between 2 slides and viewed under a dissecting microscope so that indistinct or closely spaced annual increments could be counted.

Analysis of notata marking: The uncut valve from each clam specimen was also scored for the presence of notata markings characteristic of Mercenaria mercenaria f. notata (Humphrey \& Walker 1982). The notata feature, inherited in a manner indicative of control by a single gene or by several closely linked genes (Humphrey \& Walker 1982), is the only available morphological marker in Mercenaria that expresses such a clear inheritance pattern, but it can serve as a proxy for other heritable characteristics. Hard clams express the heterozygous notata condition as a series of brown bands on the external surface of the shell, whereas those that are homozygous for notata express solid brown bands (Chanley 1961). Heterozygotes occur in $<2 \%$ of natural hard clam populations, at least in the southeastern USA, and homozygotes are extremely rare (Humphrey \& Walker 1982).

\section{RESULTS}

We collected a total of 585 hard clams from 1 site in Georgia and 11 sites in Florida (Fig. 1). We also collected 87 hard clams from an aquaculture lease site in Cedar Key on the west coast of Florida, so that we could estimate the genetic composition of cultured hard clams being used in the Florida aquaculture industry. Based upon the known age of the clam and backdating from the known collection date, none of the clams that we collected were hatched more recently than 2003 and the oldest clams we collected were hatched in 1985. Mean shell height (SH: maximum distance from umbo to ventral margin) spanned the range from $47.6 \mathrm{~mm}$ (Cedar Key aquaculture sample) to $105.3 \mathrm{~mm}$ (Charlotte Harbor) (Table 1). The smallest clam we collected was $23.0 \mathrm{~mm} \mathrm{SH}$, and the largest clam was $141.6 \mathrm{~mm} \mathrm{SH}$ (Table 1). Mean SH differed significantly between sites (1-way ANOVA, $F=$ 70.3, df $=12$, p $<0.0001$ ), and a comparison of means using the Tukey procedure (appropriate for unequal sample size and effective at controlling the mean experiment-wise error rate) revealed several subgroups with respect to mean $\mathrm{SH}$ (Table 1). Of the 672 clams that we originally collected, 5 were not included in the analyses because we were unable to age them (2 from Wassaw Sound, 2 from Pensacola) or to establish a definitive genotype identity (1 from Sebastian).

Consistent with our previous allozyme-based classifications of Mercenaria spp. to genotype class (e.g. Bert et al. 1993, Bert \& Arnold 1995, Arnold et al. 1996, 2004), the M. mercenaria and $M$. campechiensis genotype classes were distinguished by allele frequency differences that were essentially diagnostic at the DPEP2 and GPI loci, with lesser contributions from the AAT and PGM loci. We compared relative allele frequency among species for each locus, using 100 as indicative of the most common allele for each enzyme (Fig. 2). For DPEP2, M. mercenaria was characterized by the 100 and 102 alleles, whereas M. campechiensis was characterized almost exclusively by the 92 allele, with minor contributions from the 98 allele. At the GPI locus $M$. mercenaria was characterized by the 100 allele, whereas the 110 to 125 alleles predominated in the $M$. campechiensis populations. We did detect some hybrids in both the $M$. mercenaria group (those populations included in Fig. 3) and the M. campechiensis group (those populations included in Fig. 4), so the occasional appearance of alleles characteristic of a pure-species genotype class in the Fig. 2 plot for the other pure-species genotype class is to be expected. Both AAT and PGM2 were less reliable indicators for assigning genotype class, but both had value particularly with regard to rare alleles. For AAT, occurrence of the 100 allele provided little additional information for 
assignment of an individual to a genotype class, but rarer alleles such as 95 or 110 were strongly indicative of membership in the $M$. campechiensis genotype class. Similarly, both species shared alleles at the PGM2 locus, but the occurrence of the 98 variant
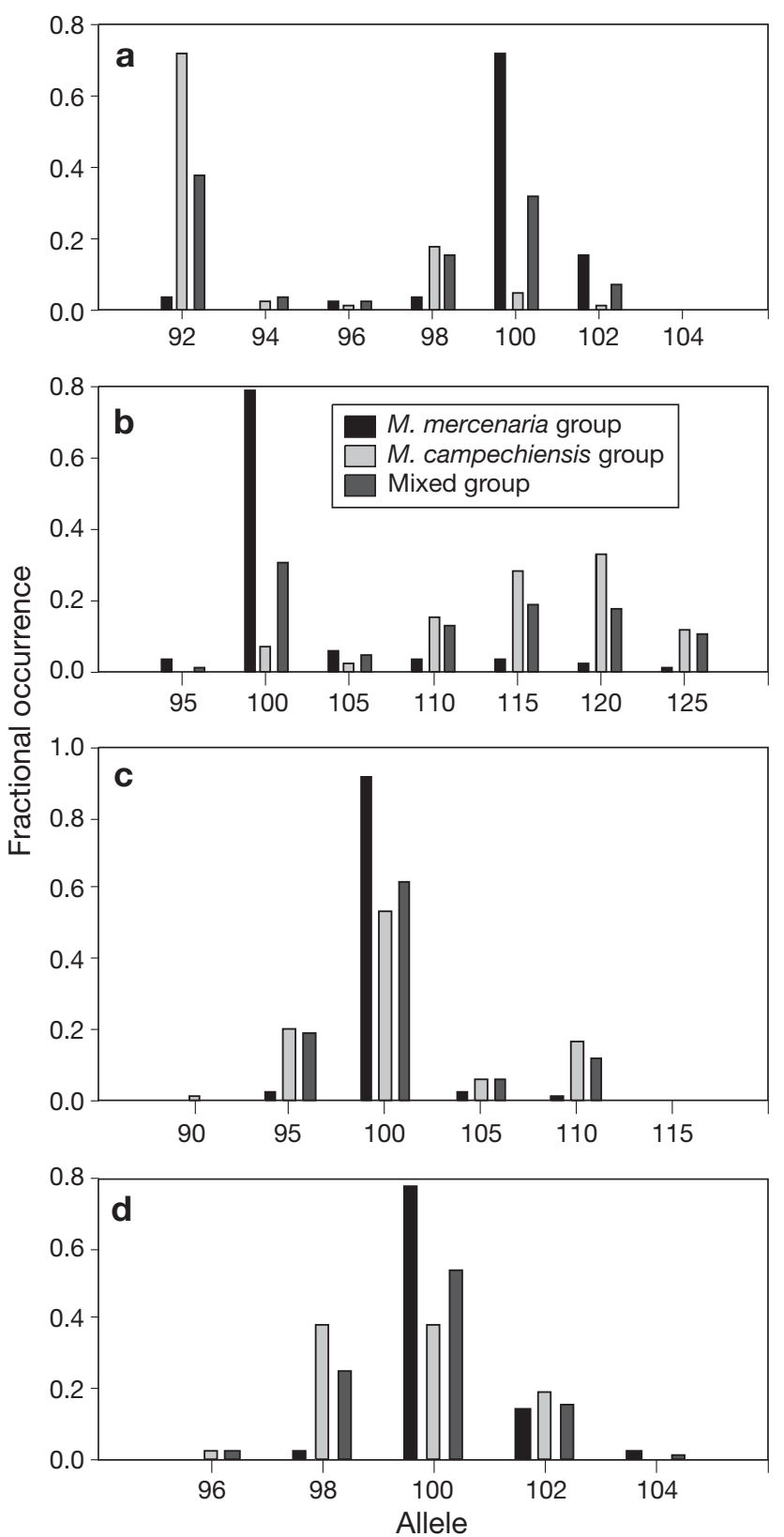

Fig. 2. Mercenaria spp. Fractional occurrence of the various alleles that were detected for each of 4 enzymes assayed to determine genotype class assignments for Mercenaria spp.: (a) DPEP2, (b) GPI, (c) AAT, and (d) PGM2. Each allele is plotted according to its relative mobility across the gel, with 100 being the most common allele for each enzyme. The M. mercenaria group includes the clams harvested from the sites included in Fig. 3, the M. campechiensis group includes the clams harvested from sites included in Fig. 4, and the mixed group includes the clams harvested from sites included in Fig. 5 was strongly indicative of membership in the $M$. campechiensis genotype class.

We were able to collect enough samples from the east coast populations to statistically analyze the populations' genotype compositions before versus after aquaculture introduction only at the Mosquito Lagoon site. There, we detected no statistically significant change in genotype composition following the advent of aquaculture $(\mathrm{R} \times \mathrm{C}$ G-test of independence with Williams' correction for small sample size [Sokal \& Rohlf 1995], $G=3.9^{\text {ns }}$, $d f=2$; Table 4 ). We did find a single specimen of Mercenaria campechiensis in Mosquito Lagoon, but that clam was hatched prior to the advent of aquaculture in Mosquito Lagoon. At the
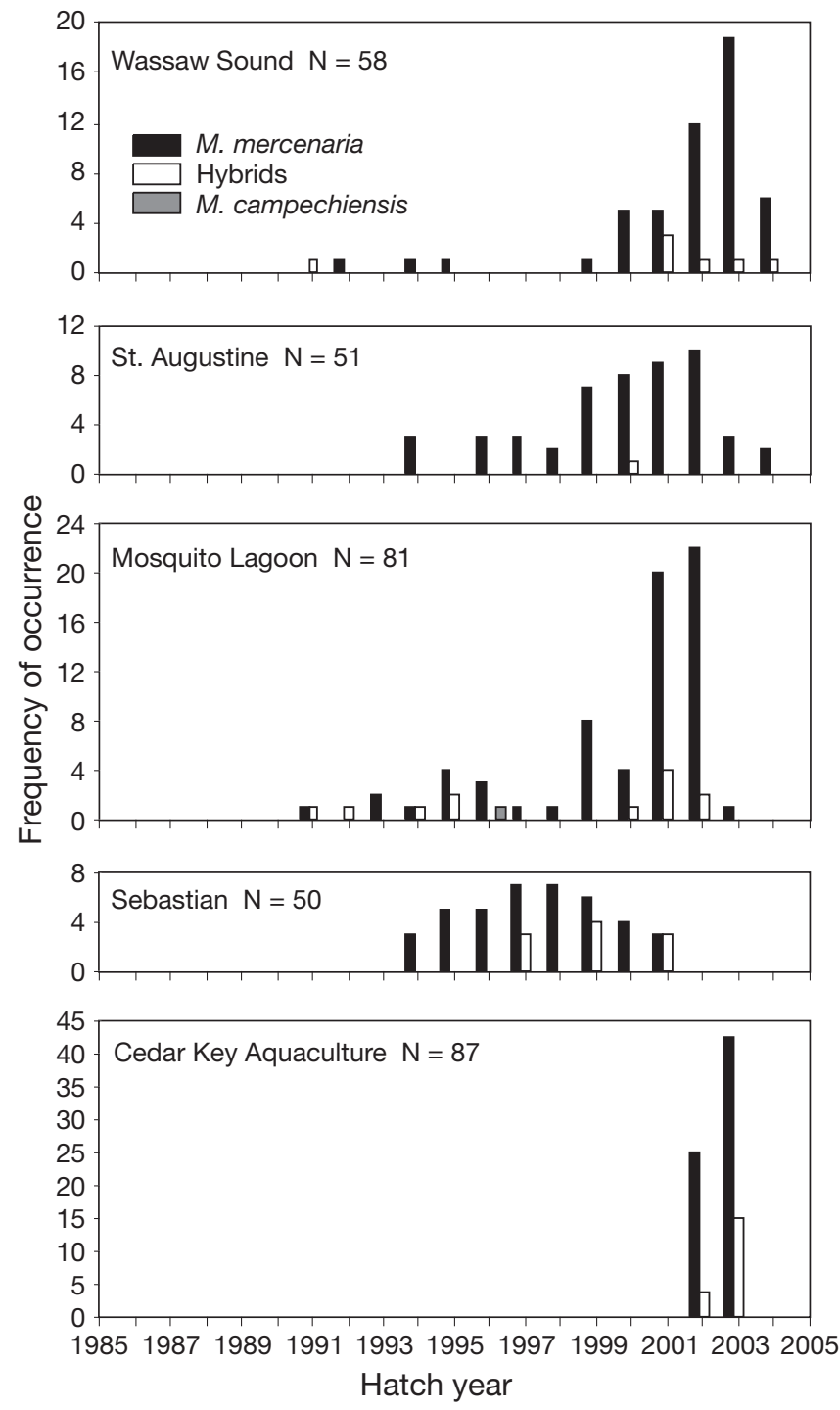

Fig. 3. Mercenaria spp. Abundance of M. mercenaria, $M$. campechiensis, and hybrids collected from Wassaw Sound, Georgia; from 3 sites along the east coast of Florida; and from a hard clam aquaculture lease site in Cedar Key on the west coast of Florida 


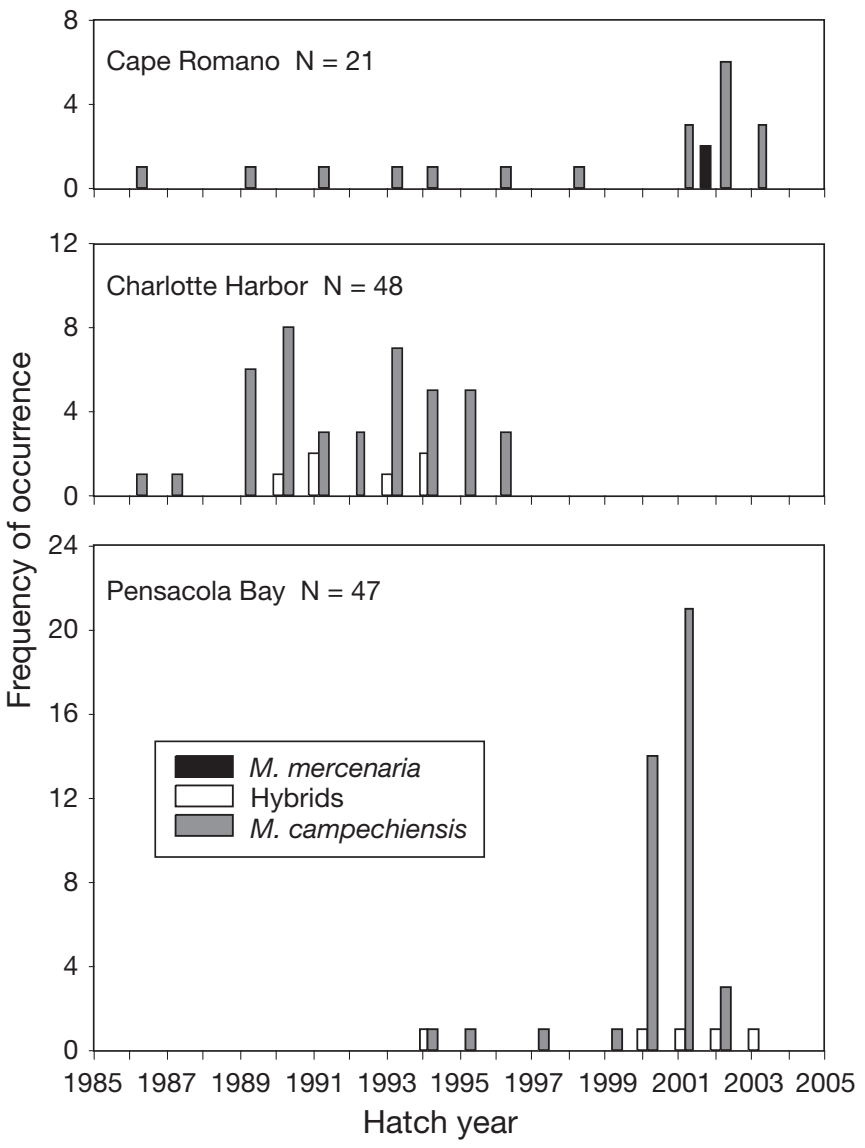

Fig. 4. Mercenaria spp. Abundance of M. mercenaria, $M$. campechiensis, and hybrids of the 2 species collected along the west coast of Florida at 3 sites where no $M$. mercenaria introductions have been documented (Table 3)

remaining east coast sites (Fig. 3), aquaculture had either not yet been introduced at the time of our sampling (Wassaw Sound) or the clams we collected were almost exclusively hatched following the advent of aquaculture (St. Augustine and Sebastian). Hard clams collected from east coast sites would be expected to exhibit little if any change in the genotype composition of the population following the introduction of aquaculture, because those sites are naturally characterized by $M$. mercenaria populations (Baker et al. 2008), with only small numbers of hybrids, and that same genotype distribution is found in the population of cultured hard clams (Fig. 3).

At those west coast sample sites where scientific or commercial hard clam aquaculture operations have not yet been documented, the hard clam population was predominantly Mercenaria campechiensis, with a small proportion of hybrid clams (Fig. 4). Only at the Cape Romano site did we detect any M. mercenaria2 clams that were hatched in $2001(<2$ yr prior to our sampling efforts). At both the Charlotte Harbor and
Table 4. Mercenaria spp. Column and row values for $\mathrm{R} \times \mathrm{C}$ $G$-tests of independence applied to hard clam samples collected from Mosquito Lagoon and Pine Island Sound

\begin{tabular}{|lrrcc|}
\hline Hatch date & $\begin{array}{c}\text { M. mer- } \\
\text { cenaria }\end{array}$ & Hybrid & $\begin{array}{c}\text { M. cam- } \\
\text { pechiensis }\end{array}$ & Total \\
\hline Mosquito Lagoon & & & & \\
After aquaculture & 55 & 7 & 0 & 62 \\
Before aquaculture & 13 & 5 & 1 & 19 \\
Total & 68 & 12 & 1 & 81 \\
Pine Island Sound & & & & \\
After aquaculture & 11 & 4 & 15 & 30 \\
Before aquaculture & 0 & 6 & 13 & 19 \\
Total & 11 & 10 & 28 & 49 \\
\hline
\end{tabular}

Pensacola Bay sites, $M$. mercenaria were nonexistent in our samples. Hybrids were detected at both of those sites, but in relatively low numbers.

At those west coast sites where Mercenaria mercenaria had been successfully introduced for scientific investigations, commercial aquaculture, or both, the genotype composition of the population was site specific (Fig. 5). Aquaculture was initiated at the Pine Island Sound site in 1997, with an expected initial (detectable) effect beginning in 1998. There, we observed a statistically significant change in genotype composition between those clams hatched prior to 1998 and those clams hatched during 1998 or later $(\mathrm{R} \times \mathrm{C}$ G-test of independence with Williams' correction, $G=13.3^{* *}$, $\mathrm{df}=2$; Table 4 ). The relative abundance of $M$. campechiensis and hybrids did not change substantially after the introduction of aquaculture as compared to that recorded in clams hatched before the introduction of aquaculture. In contrast, we found no M. mercenaria that were hatched prior to the advent of aquaculture versus $11 \mathrm{M}$. mercenaria (22\% of total sample size) that were hatched following introduction of cultured M. mercenaria. At the Tampa Bay and Alligator Harbor sites, M. mercenaria were introduced in the late 1950s and early 1960s (Menzel 1961, Woodburn 1961, Menzel \& Sims 1962). At the Alligator Harbor and Tampa Bay Oyster Reef sites, where all clams were harvested from oyster beds, we found no $M$. campechiensis, and the population was dominated by M. mercenaria. At the Tampa Bay Sand Flat site, characterized as a mixed Thalassia/Halodule seagrass bed, but devoid of oysters, we found only $1 \mathrm{M}$. mercenaria specimen, and the population was dominated by $M$. campechiensis. Clams were collected from a similar sand-seagrass habitat in Sarasota Bay, and there we also found no $M$. mercenaria and only a small number of hybrid hard clams.

Hard clams collected from commercial growout bags deployed in the nearshore waters of Cedar Key were predominantly $(78 \%)$ Mercenaria mercenaria; no $M$. 


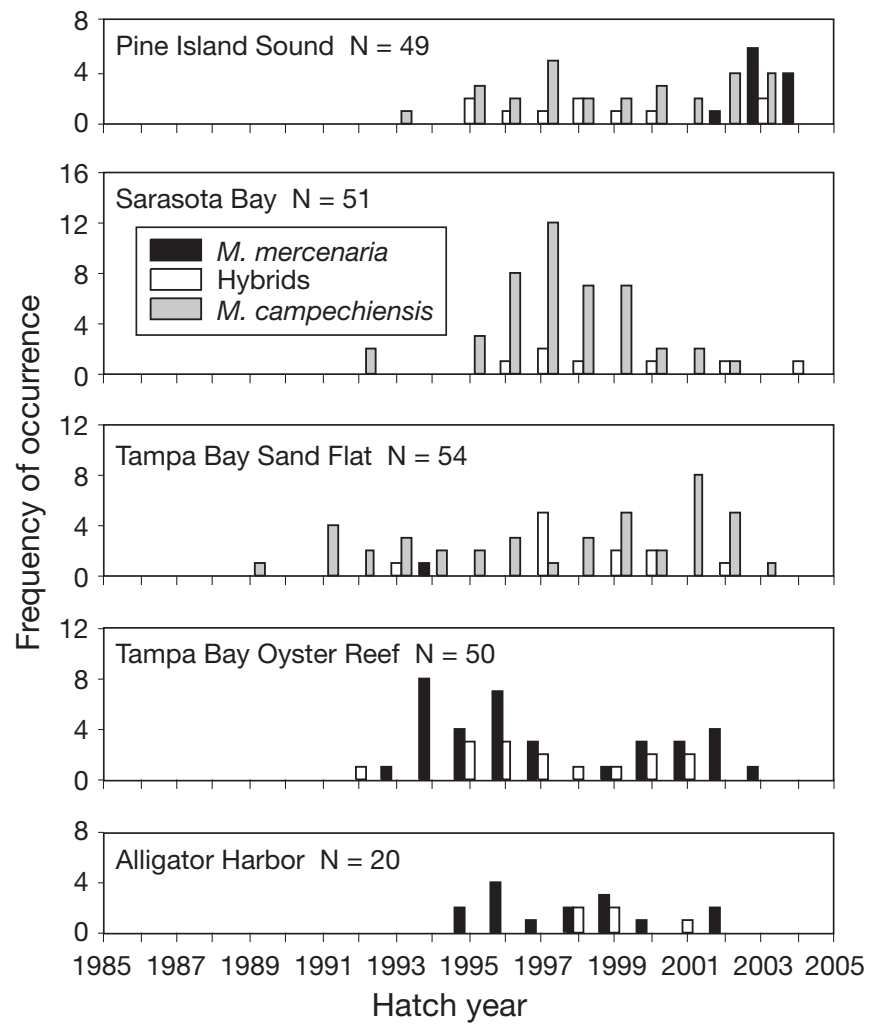

Fig. 5. Mercenaria spp. Abundance of M. mercenaria, $M$. campechiensis, and hybrids collected along the west coast of Florida at 5 sites where $M$. mercenaria introductions have been documented (Table 3 )

campechiensis were detected in this sample (Fig. 3). This result is not surprising because most of the original broodstock from which the Cedar Key clams are descended were collected from the Indian River Lagoon on the east coast of Florida. There, the hard clam population is predominantly $M$. mercenaria, with variable percentages of hybrids and $M$. campechiensis, depending upon sample location (Bert \& Arnold 1995, Arnold et al. 1996).

Discriminant function analysis assigned each animal to a genotype class (Mercenaria mercenaria, $M$. campechiensis, or hybrid) and also generated a posterior probability of membership in that genotype class. For hybrids, if that probability was $<1.00$, the residual probability was distributed between the 2 pure-species genotype classes. Although the highest probability of membership for these clams was in the hybrid genotype class, there remained some probability of membership in each of the 2 pure-species genotype classes, because it was rare that any clam was classified to the hybrid genotype class with $100 \%$ probability. Because these relative probabilities reflect the genotype composition of the clams, they indicate the predominance of pure-species alleles in the individual (assuming that the allozyme loci we analyzed represent the genome in general). To further assess the contribution of each species to the composition of the hybrid population, we compared the posterior probability of membership in each of the 2 pure-species genotype classes for all clams that were classified as hybrids (Arnold et al. 2004). For all sites combined, the mean posterior probability that the 108 hybrids that we identified were members of the hybrid group was $0.88( \pm 0.15 \mathrm{SD}) ; M$. mercenaria predominantly contributed the remainder of the posterior probability $(0.09 \pm 0.14)$, with $M$. campechiensis contributing only a small probability $(0.03 \pm 0.09)$.

Comparing the posterior probabilities of hybrids collected from the individual sites provides guidance as to the predominant species-specific contribution to hybrid individuals at each site. For the pooled east coast sites, the mean posterior probability of inclusion in the Mercenaria mercenaria group was 0.15 versus 0.01 for $M$. campechiensis. The reverse was true for those west coast sites with no history of introduction of $M$. mercenaria. There, the mean posterior probability of inclusion in the $M$. campechiensis group was 0.13 versus 0.00 for M. mercenaria. The remainder of the west coast sites can be divided into those sites where M. campechiensis predominates (Sarasota Bay and Tampa Bay Sand Flat), those sites where M. mercenaria predominates (Alligator Harbor and Tampa Bay Oyster Reef), and the Pine Island Site, where the relative influence of the 2 pure species has changed contemporaneously with the introduction of $M$. mercenaria aquaculture. For hybrid clams collected at the Sarasota Bay and Tampa Bay Sand Flat sites, the mean posterior probability of membership in either of the 2 pure-species classes was approximately 0.01. In contrast, at the Alligator Harbor and Tampa Bay Oyster Reef sites, the mean posterior probability of membership in the M. mercenaria class substantially exceeded that for membership in the $M$. campechiensis class (0.08 vs. 0.00). For those clams in Pine Island Sound that were hatched in 1997 or earlier, the posterior probability of membership in the $M$. campechiensis group was 0.13 , whereas the posterior probability of membership in the $M$. mercenaria group was 0.00 . Again, those probabilities essentially reversed following the introduction of aquaculture. For clams hatched in 1998 or later, the posterior probability of membership in the $M$. campechiensis group was 0.02 , whereas the posterior probability of membership in the $M$. mercenaria group was 0.14 . The 19 hybrid clams collected from Cedar Key were most strongly influenced by $M$. mercenaria, with an average posterior probability of 0.17 compared with an average of 0.10 for $M$. campechiensis membership.

Some clams collected from each of our 12 field study sites expressed a neoplastic condition (Figs. 6 to 8). 
When comparing each of the 3 clam groups (east coast clams, west coast clams from sites where Mercenaria mercenaria was previously introduced ['exposed'], west coast clams from sites with no history of such introductions ['pristine']), and including all of our neoplasia classification stages, we detected a significant difference in the median stage of neoplasia among groups (Wilcoxon test, Chi-squared $=11.90, \mathrm{df}=2, \mathrm{p}=$ 0.0026). A Tukey's studentized range test revealed that clams from the east coast group (Fig. 6) had a significantly higher median neoplasia score than did clams from the pristine west coast group (Fig. 7); neither of those 2 groups differed significantly in median neoplasia score from that of clams collected from the exposed west coast group (Fig. 8). When we compared the median stage and considered only those clams that did express a neoplastic condition (Stage 1.5 or higher), we again detected a significant difference (Wilcoxon test, Chi-squared $=13.23, \mathrm{df}=2, \mathrm{p}=0.0013$ ). In this case, clams from the exposed west coast group suffered a more intense level of affliction than did clams from either of the other 2 groups, whereas affliction in the east coast group and the pristine west coast group did not significantly differ. That difference between the exposed west coast group and the 2 other groups can be attributed to hybridization. Pooling clams from all sites, we detected a significant difference in the median stage of neoplasia among genotype classes for those clams that were afflicted with neoplasia (Wilcoxon test,

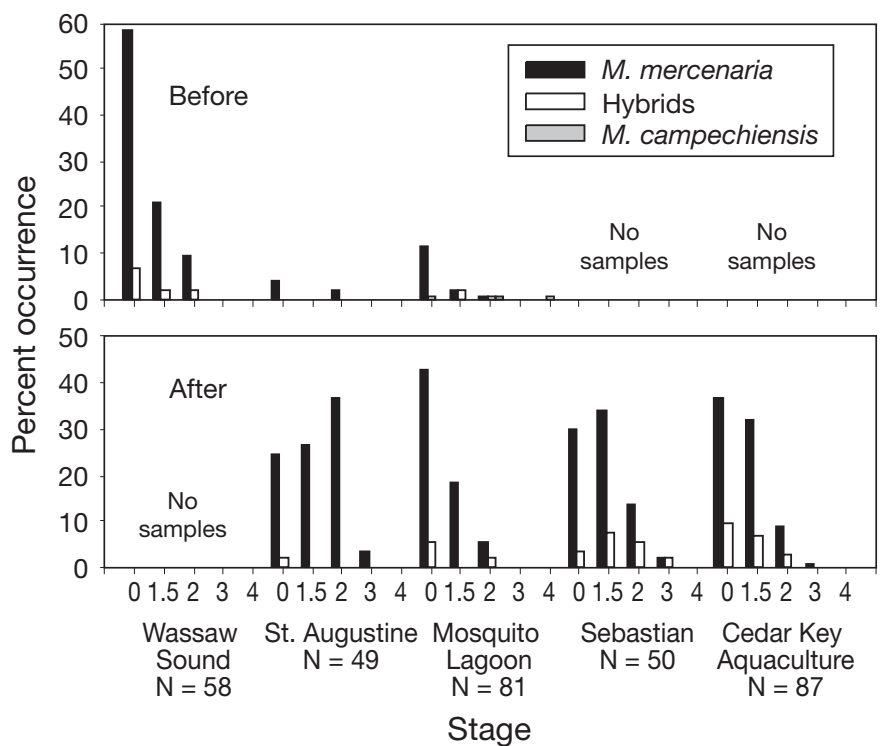

Fig. 6. Mercenaria spp. Frequency of occurrence of each of 6 stages (see Table 3) of gonadal neoplasia in M. mercenaria, M. campechiensis, and hybrids collected from Wassaw Sound, Georgia; from 3 sites along the east coast of Florida; and from a hard clam aquaculture lease site in Cedar Key, Florida. Occurrence is presented within each site for all clams hatched before (upper panel) and after (lower panel) the introduction of aquaculture
Chi-squared $=9.04, \mathrm{df}=2, \mathrm{p}=0.0109$ ), and that difference could be attributed to a significantly greater intensity of affliction in the hybrid clams compared with the pure-species genotype classes. We detected no significant difference in the intensity of affliction
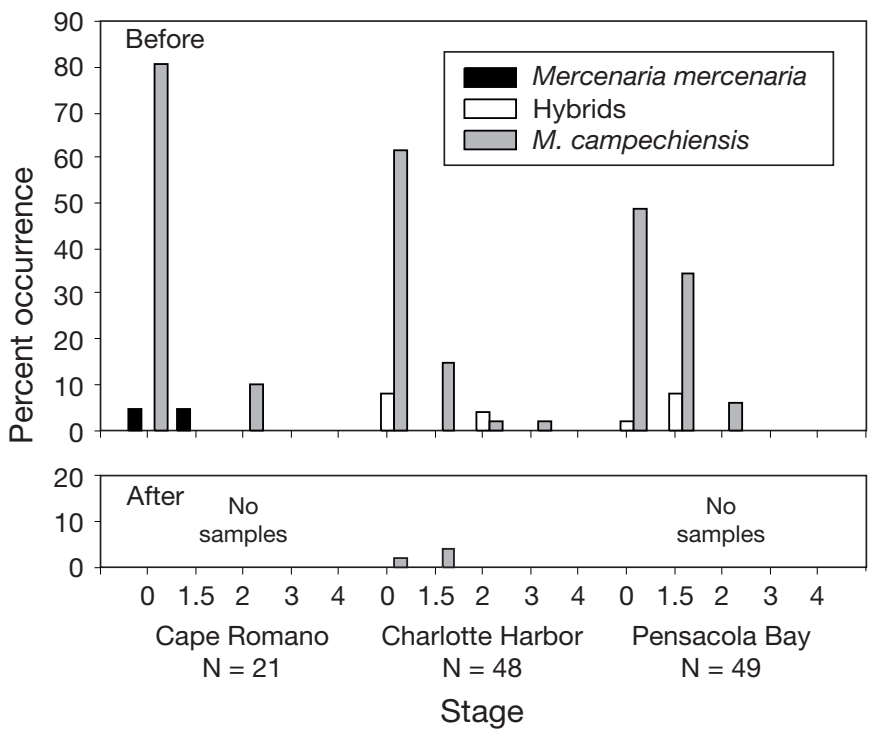

Fig. 7. Mercenaria spp. Frequency of occurrence of each of 6 stages (see Table 3 ) of gonadal neoplasia in $M$. mercenaria, M. campechiensis, and hybrids collected along the west coast of Florida at 3 sites where $M$. mercenaria introductions have not been documented. Occurrence is presented within each site for all clams hatched before (upper panel) and after (lower panel) the introduction of aquaculture at that site

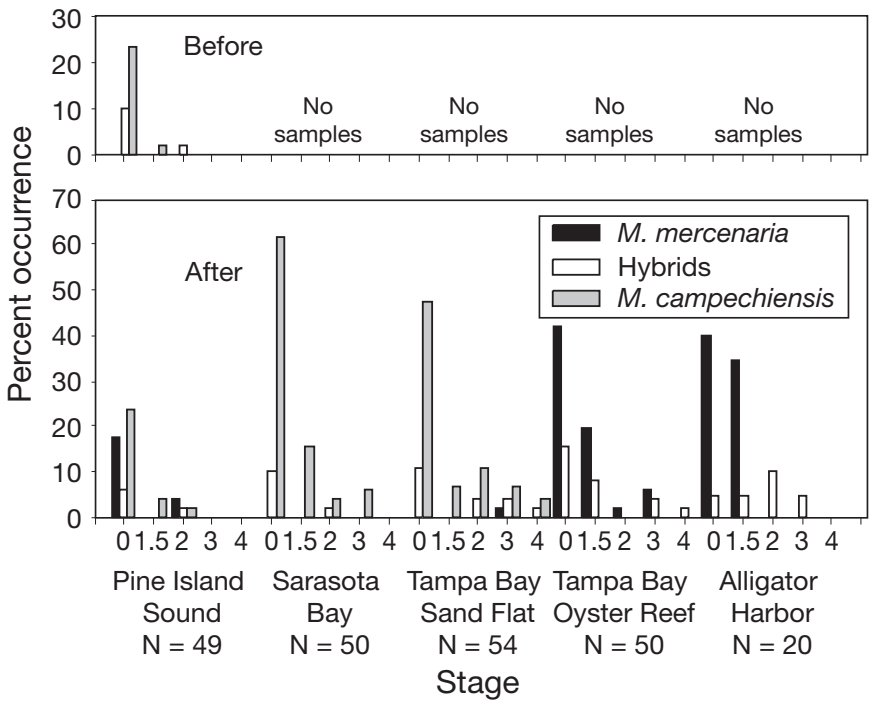

Fig. 8. Mercenaria spp. Frequency of occurrence of each of 6 stages (see Table 3) of gonadal neoplasia in $M$. mercenaria, $M$. campechiensis, and hybrids collected along the west coast of Florida at 5 sites where $M$. mercenaria introductions have been documented. Occurrence is presented within each site for all clams hatched before (upper panel) and after (lower panel) the introduction of aquaculture at that site 
between $M$. mercenaria and $M$. campechiensis. Despite the young age of the Cedar Key clams, we detected the disease in $42 \%$ of the sampled clams, including $13 \%$ in advanced ( 2 to 4 ) stages.

The overall frequency of occurrence of the 'notata' form in our collections from the 12 wild populations was $21.9 \%$ in Mercenaria mercenaria, $21.3 \%$ in hybrids, and $4.5 \%$ in $M$. campechiensis. The occurrence of the 'notata' form was most common at those west coast sites that previously experienced introduction of $M$. mercenaria. There, $12.0 \%$ of hard clams expressed notata marking, compared with $5.4 \%$ of clams collected from the east coast sites and $0.8 \%$ of clams collected from pristine west coast sites. In comparison, $77.0 \%$ of the clams collected from the Cedar Key aquaculture operation expressed notata markings. For the wild populations, the 'notata' form was most common at Pine Island Sound, Mosquito Lagoon, and the Tampa Bay Sand Flat site (Table 5). Although the 'notata' form has been assigned to the species $M$. mercenaria (Humphrey \& Walker 1982, but see Menzel 1968), we recorded $10 \mathrm{M}$. campechiensis that expressed the marking, 8 of which were harvested from the Tampa Bay Sand Flat site.

\section{DISCUSSION}

Commercial-scale hard clam aquaculture in Floridian GOM waters began in 1993, and our initial investigation of the effect of that introduction of Mercenaria mercenaria into the midst of a $M$. campechiensis population (Arnold et al. 2004) revealed a statistically significant change in genotype composition of the wild population. The present study was undertaken to determine if similar changes had occurred at other sites in Florida, particularly west coast sites historically characterized by $M$. campechiensis populations, in response to similar $M$. mercenaria introductions. We also wished to determine if earlier and smaller scale introductions, originating from scientific investigations of the feasibility of hard clam aquaculture in Florida (Menzel 1961, Woodburn 1961, Menzel \& Sims 1962), resulted in similar changes in genotype composition in the resident population. Our results indicate that such changes in the population genome have occurred at all Floridian GOM sites where documented introductions of $M$. mercenaria have occurred. The magnitude of the introduction does not appear to have substantially influenced the outcome, because clams in both Alligator Harbor, where only small scientific introductions occurred, and in Cedar Key, where a major M. mercenaria aquaculture industry has been operating since 1993, now predominantly express $M$. mercenaria or hybrid genotypes. Instead, the genetic fate of the
Table 5. Mercenaria spp. Percent frequency of occurrence of the 'notata' shell coloration form within 3 genotype classes of hard clams collected from wild populations at Wassaw Sound, Georgia, at various sites throughout Florida, and from a Cedar Key aquaculture site (n in parentheses)

\begin{tabular}{|lrrr|}
\hline Collection site & $\begin{array}{r}\text { M. mer- } \\
\text { cenaria }\end{array}$ & Hybrid & $\begin{array}{c}\text { M. cam- } \\
\text { pechiensis }\end{array}$ \\
\hline Wassaw Sound, GA & $1.9(1)$ & $0(0)$ & $0(0)$ \\
St. Augustine & $0(0)$ & $0(0)$ & $0(0)$ \\
Mosquito Lagoon & $10.3(7)$ & $16.7(2)$ & $0(0)$ \\
Sebastian & $5.0(2)$ & $10.0(1)$ & $0(0)$ \\
Cape Romano & $0(0)$ & $0(0)$ & $5.3(1)$ \\
Pine Island Sound & $63.6(7)$ & $10.0(1)$ & $3.6(1)$ \\
Charlotte Harbor & $0(0)$ & $0(0)$ & $0(0)$ \\
Sarasota Bay & $0(0)$ & $0(0)$ & $0(0)$ \\
Tampa Bay Sand Flat & $100.0(1)$ & $36.4(4)$ & $19.0(8)$ \\
Tampa Bay Oyster Reef & $0(0)$ & $13.3(2)$ & $0(0)$ \\
Alligator Harbor & $6.7(1)$ & $40.0(2)$ & $0(0)$ \\
Pensacola & $0(0)$ & $0(0)$ & $0(0)$ \\
Cedar Key Aquaculture & $82.4(56)$ & $57.9(11)$ & $0(0)$ \\
\hline
\end{tabular}

population appears to be more strongly influenced by habitat and by the duration of availability of $M$. mercenaria alleles.

All of the hard clams that we collected from both the Alligator Harbor and Tampa Bay Oyster Reef sites were harvested from within an oyster reef. Clams from both of these populations were predominantly Mercenaria mercenaria, with few hybrids and no $M$. campechiensis. At the Alligator Harbor site, we also searched for clams in the sand flats that are common in that area, but we could find no individuals of Mercenaria spp. In contrast, we had little trouble collecting hard clams from sand flat habitats in Tampa Bay. Remarkably, although the oyster-reef habitat that we sampled in Tampa Bay was surrounded by the intertidal sand-flat habitat from which we also collected clams, those 2 habitats support clam populations that express distinct genotypes. Hard clam larvae are probably available to colonize both habitats in Tampa Bay, suggesting that postsettlement selective processes are maintaining these genetically distinct populations. However, we sampled from a similar intertidal habitat in Pine Island Sound and found both species and their hybrid forms living side-by-side, and such sympatric distributions are also common in the hard clam population of the Indian River Lagoon (Arnold et al. 1996).

Although many factors could contribute to the difference in the genetic constitution of hard clam populations between the Tampa Bay and Pine Island Sound intertidal sand flat habitats, a distinct difference is the level of hard clam aquaculture activity at the 2 sites. At the time of our sampling and before that, there had been no commercial-scale hard clam aquaculture in Tampa Bay, and the only documented anthropogenic 
introduction of Mercenaria mercenaria alleles into that system occurred in November 1960 (Woodburn 1961). Apparently, those $M$. mercenaria have been able to maintain themselves as a distinct population since that original introduction, using a habitat that is not used by $M$. campechiensis and that therefore serves as a longterm refuge for $M$. mercenaria alleles in a nonindigenous location. In Pine Island Sound, M. mercenaria are able to maintain themselves in the intertidal sand flat habitat. This may be because of the continuous influx of $M$. mercenaria alleles from nearby active hard clam aquaculture operations. All of the M. mercenaria living in that habitat were spawned after the initiation of aquaculture, suggesting that successful colonization by $M$. mercenaria is dependent upon the continued supply of propagules from those aquaculture operations. Because there are no oyster reefs within the vicinity of those hard clam aquaculture operations and because we have not analyzed clams harvested from more distant oyster reefs near the mouth of the Caloosahatchee River, we cannot yet determine if $M$. mercenaria populations have been established in those reefs. Similarly, we did not collect clams from oyster reefs in Sarasota Bay, and we did not detect M. mercenaria in our sample from that bay. It may be possible that refuge populations of $M$. mercenaria occupy oyster reef habitats in Sarasota Bay and elsewhere along the west coast of Florida.

The clams we collected from Sarasota Bay and the Tampa Bay Sand Flat site were harvested from intertidal or shallow subtidal sand flats supporting moderate to dense seagrass beds (primarily Thalassia testudinum with some Syringodium filiforme). At those sites and our other 3 west coast collection sites, Mercenaria campechiensis dominated populations that were also composed of a small percentage of hybrids and a total of only 3 individual M. mercenaria. These sandflat/ seagrass sites therefore appear to be the habitat of choice of $M$. campechiensis, or at least the habitat within which they maintain a selective advantage with respect to $M$. mercenaria.

Gonadal neoplasia occurs in all of the Florida hard clam populations that we sampled, but the intensity of the disease varies with the genotype composition of the resident population. Although hybrid clams appear to be no more susceptible to the disease than their pure-species kin are, they suffer to a greater degree than pure species Mercenaria mercenaria and $M$. campechiensis (Bert et al. 1993). It is not clear from our data if the 2 pure-species experience a lower mean intensity of the disease than hybrids do because they are resistant to progression or because the intensity level at which they die is lower than it is for hybrids. The disease may or may not progress to a fatal outcome, but it does reduce fecundity (Hesselman et al.
1988). If the species-specific refuges that we describe for Mercenaria spp. in the GOM are incomplete or break down, with the result that eventually all hard clams in the GOM are of the hybrid form, then the fitness of the species will be reduced due to increased susceptibility to gonadal neoplasia and concomitant reduction in fecundity.

Effects on wild hard clam populations from introduction of cultured clams are not limited to the west coast of Florida or to gonadal neoplasia. Although introgression of Mercenaria mercenaria alleles into M. campechiensis individuals is more apparent than introgression of $M$. mercenaria alleles into $M$. mercenaria individuals and is more significant with regard to species integrity, subtle effects such as that exemplified by the 'notata' characteristic also may affect $M$. mercenaria populations. The 'notata' form appears to be inherited in a simple Mendelian fashion (Chanley 1961, Humphrey \& Walker 1982), and the feature has been exploited by Florida hard clam farmers to distinguish cultured clams from wild clams. Thus, notata clams were very common in our sample from a Cedar Key aquaculture operation, and similarly marked clams have been planted in Mosquito Lagoon and Pine Island Sound (W. S. Arnold pers. obs.). At both of those sites, wild hard clams expressing the notata marking are quite common. In contrast, that shell feature is found in only about $2 \%$ of the members of wild hard clam populations in areas of Georgia and South Carolina, where cultured hard clams have not been previously introduced (Humphrey \& Walker 1982). Even at sites where $M$. mercenaria were introduced for the short-term and relatively small-scale scientific studies conducted from 1958 to 1960 (Menzel 1961, Woodburn 1961, Menzel \& Sims 1962), clams expressing the notata marking are common. The pattern of notata marking that we observed in our hard clams indicates a heterozygous condition; in our samples and in previously analyzed samples (Humphrey \& Walker 1982) the homozygous condition is very rare, suggesting that the gene(s) coding for the notata marking is (are) deleterious. Increased frequency of notata is just the most apparent reflection of introgression of foreign or uncommon alleles into wild hard clams from introduced cultured clams, but it is likely that other less obvious changes to the genome of the wild population have also occurred. The long-term ecological effects of those changes, whether positive or negative, may not become apparent for many years (Bert et al. 2007).

A variety of sources suggest that Mercenaria campechiensis is the indigenous species of hard clam on the west coast of Florida and that $M$. mercenaria did not occur in the GOM prior to human introductions (Baker et al. 2008). Analyses of the mitochondrial 16s rRNA gene in Mercenaria collected from various local- 
ities (including 3 sites in the GOM) revealed a complex pattern of secondary contact and introgression between western GOM Mercenaria taxa, including $M$. campechiensis and the original, but relict, Mercenaria lineages that predate modern specimens (Ó Foighil et al. 1996). Those authors reported no contribution from M. mercenaria. A similar historical perspective was provided by Dillon \& Manzi (1989a) using results from morphological and allozyme analyses of clams collected near Cedar Key, Florida, and their data agreed with ours from work in that same region (Arnold et al. 2004). Finally, Baker et al. (2008) conducted a rangewide mitochondrial DNA analysis of $M$. mercenaria and concluded that the occurrence of that species in the GOM is the result of recent introductions. There is no evidence suggesting that $M$. mercenaria has historically occupied GOM habitats; published reports indicate that $M$. campechiensis historically has been the hard clam of the GOM. The work of Menzel (1968) supports that contention.

The introduction of Mercenaria mercenaria into the GOM, documented to have begun in the late 1950s and continuing to the present day, does threaten the status of $M$. campechiensis as a pure species in the eastern GOM. Although we are still able to collect individuals of the latter species that are apparently devoid of $M$. mercenaria alleles, those specimens appear to be increasingly rare in the natural environment. Even in intertidal seagrass habitats where $M$. campechiensis appears to have a distinct selective advantage, hybrids of the 2 species are common. It may simply be a matter of time before anything other than hybrids can be found in the eastern GOM, because $M$. mercenaria alleles appear to be introgressing into the $M$. campechiensis genome. A refuge for $M$. campechiensis does exist in relatively deep offshore waters along the Atlantic coast of the USA, and that refuge may serve to maintain the species (Menzel 1968, Abbott 1974). We have no information on genetic linkages that may exist between Atlantic offshore $M$. campechiensis populations and the nearshore populations of the GOM, but if those nearshore populations provide propagules that are transported via ocean currents to the Atlantic offshore populations, then over evolutionary time that refuge may also be at risk. Such genetic connectivity has been described for the similarly distributed calico scallop Argopecten gibbus (Krause et al. 1994). Clearly, even small introductions of nonindigenous species may have significant effects on indigenous populations, and those effects may be far-reaching on temporal as well as spatial scales.

Acknowledgements. Hard clam samples were collected with the assistance of John Gunter, Janessa Cobb, Cindy Meyer, Matt Finn, Randy Penn, Amber Castillo, Jon Fajans, Alan
Power, Hank Sterling, Robert Turpin, April Granholm, and Anna Cucknell. Theresa Bert assisted with scoring allozyme gels, and she, along with Gabriel Delgado, Jim Quinn, and Judy Leiby, provided preliminary reviews of the manuscript.

\section{LITERATURE CITED}

Abbott RT (1974) American seashells: the marine Mollusca of the Atlantic and Pacific coasts of North America, 2nd edn. Van Nostrand Reinhold, New York

Arnold WS (1984) The effects of prey size, predator size, and sediment composition on the rate of predation of the blue crab (Callinectes sapidus Rathbun) on the hard clam (Mercenaria mercenaria Linné). J Exp Mar Biol Ecol 80:207-219

> Arnold WS, Marelli DC, Bert TM, Jones DS, Quitmyer IR (1991) Habitat-specific growth of hard clams Mercenaria mercenaria (L.) from the Indian River, Florida. J Exp Mar Biol Ecol 147:245-265

Arnold WS, Bert TM, Marelli DC, Cruz-Lopez H, Gill PA (1996) Genotype-specific growth of hard clams (genus Mercenaria) in a hybrid zone: variation among habitats. Mar Biol 125:129-139

Arnold WS, Bert TM, Quitmyer IR, Jones DS (1998) Contemporaneous deposition of annual growth bands in Mercenaria mercenaria (Linnaeus), Mercenaria campechiensis (Gmelin), and their natural hybrid forms. J Exp Mar Biol Ecol 223:93-109

Arnold WS, Marelli DC, Parker M, Hoffman P, Frischer M, Scarpa J (2002) Enhancing hard clam (Mercenaria spp.) population density in the Indian River Lagoon, Florida: a comparison of strategies to maintain the commercial fishery. J Shellfish Res 21:659-672

Arnold WS, Walters SL, Fajans SJ, Peters SC, Bert TM (2004) Influence of congeneric aquaculture on hard clam (Mercenaria spp.) population genetic structure. Aquac Int 12: 139-160

> Baker P, Austin JD, Bowen BW, Baker SM (2008) Range-wide population structure and history of the northern quahog (Mercenaria mercenaria) inferred from mitochondrial DNA sequence data. ICES J Mar Sci 65:155-163

Bert TM (1986) Speciation in western Atlantic stone crabs (genus Menippe): the role of geological processes and climatic events in the formation and distribution of species. Mar Biol 93:157-170

Bert TM, Arnold WS (1995) An empirical test of predictions of two competing models for the maintenance and fate of hybrid zones: both models are supported in a hard-clam hybrid zone. Evolution 49:276-289

Bert TM, Hesselman DM, Arnold WS, Moore WS, Cruz-Lopez H, Marelli DC (1993) High frequency of gonadal neoplasia in a hard clam (Mercenaria spp.) hybrid zone. Mar Biol 117:97-104

Bert TM, Crawford CR, Tringali MD, Seyoum S, Galvin J, Higham M, Lund C (2007) Genetic management of hatchery-based stock enhancement. In: Bert TM (ed) Ecological and genetic implications of aquaculture activities. Springer, Dordrecht, p 123-174

Castagna M (2001) Aquaculture of the hard clam, Mercenaria mercenaria. In: Kraeuter JN, Castagna M (eds) Biology of the hard clam. Elsevier, Amsterdam, p 675-693

Castagna M, Kraeuter JN (1977) Mercenaria culture using stone aggregate for predator protection. Proc Natl Shellfish Assoc 67:1-6

Chanley PE (1961) Inheritance of shell markings and growth in the hard clam, Venus mercenaria. Proc Natl Shellfish Assoc 50:163-169 
Colson S, Sturmer LN (2000) One shining moment known as Clamelot: the Cedar Key story. J Shellfish Res 19:477-480

Cotran RS, Kumar V, Collins T (1999) Neoplasia. In: Cotran RS, Kumar V, Collins T (eds) Pathologic basis of disease, 6th edn. WB Saunders, Philadelphia, PA, p 260-327

Dillon RT Jr, Manzi JJ (1989a) Genetics and shell morphology in a hybrid zone between the hard clams Mercenaria mercenaria and M. campechiensis. Mar Biol 100:217-222

Dillon RT Jr, Manzi JJ (1989b) Genetics and shell morphology of hard clams (genus Mercenaria) from Laguna Madre, Texas. Nautilus 103:73-77

Harte ME (2001) Systematics and taxonomy. In: Kraeuter JN, Castagna M (eds) Biology of the hard clam. Elsevier, Amsterdam, p 3-51

Hesselman DM, Blake NJ, Peters EC (1988) Gonadal neoplasms in hard shell clams Mercenaria spp., from the Indian River, Florida: occurrence, prevalence, and histopathology. J Invertebr Pathol 52:436-446

Humphrey CM, Walker RL (1982) The occurrence of Mercenaria mercenaria form notata in Georgia and South Carolina: calculations of phenotypic and genotypic frequencies. Malacologia 23:75-79

James SC, McCulloch CE (1990) Multivariate analysis in ecology and systematic: panacea or Pandora's box? Annu Rev Ecol Syst 21:129-166

Kennish MJ, Lutz RA, Rhoads DC (1980) Preparation of acetate peels and fractured sections for observation of growth patterns within the bivalve shell. In: Rhoads DC, Lutz RA (eds) Skeletal growth of aquatic organisms. Plenum Press, New York, p 597-601

Krause MK, Arnold WS, Ambrose WG Jr (1994) Morphological and genetic variation among three populations of the calico scallop, Argopecten gibbus. J Shellfish Res 13: 529-537

MacKenzie CL Jr, Taylor DL, Arnold WS (2001) A history of hard clamming. In: Kraeuter JN, Castagna M (eds) Biology of the hard clam. Elsevier, Amsterdam, p 651-673

Marelli DC, Arnold WS (1990) Effects of field depuration on survivorship of Mercenaria spp. in the Indian River lagoon, Florida. J Shellfish Res 9:315-321

Menzel RW (1961) Seasonal growth of the northern quahog, Mercenaria mercenaria and the southern quahog, $M$. campechiensis, in Alligator Harbor, Florida. Proc Natl Shellfish Assoc 52:37-46

Editorial responsibility: Nikolaos Schizas,

Mayagüez, Puerto Rico, USA
Menzel RW (1968) Cytotaxonomy of species of clams (Mercenaria) and oysters (Crassostrea). In: Proc Symp Mollusca, Jan 12-16, 1968, Part 1. Mar Biol Assoc India, Cochin, p 75-84

Menzel RW (1969) The species and distribution of quahog clams Mercenaria. Proc Natl Shellfish Assoc 60:8

Menzel W (1989) The biology, fishery and culture of quahog clams, Mercenaria. In: Manzi JJ, Castagna M (eds) Clam mariculture in North America. Developments in aquaculture and fisheries science, Vol 19. Elsevier, New York, p 201-242

Menzel RW, Sims HW (1962) Experimental farming of hard clams, Mercenaria mercenaria, in Florida. Proc Natl Shellfish Assoc 53:103-109

Neff NA, Smith GR (1978) Multivariate analysis of hybrid fishes. Syst Zool 28:176-196

Ó Foighil D, Hilbish TJ, Showman RM (1996) Mitochondrial gene variation in Mercenaria clam sibling species reveals a relict secondary contact zone in the western Gulf of Mexico. Mar Biol 126:675-683

Quitmyer IR, Jones DS (1992) Calendars of the coast: seasonal growth increment patterns in shells of modern and archaeological southern quahogs, Mercenaria campechiensis, from Charlotte Harbor, Florida. In: Marquardt WH (ed) Culture and environment in the domain of the Calusa. Monograph No. 1, Institute of Archaeology and Paleoenvironmental Studies, University of Florida, Gainesville, FL, p 247-264

Quitmyer IR, Jones DS, Arnold WS (1997) The sclerochronology of hard clams, Mercenaria spp., from the southeastern USA: a method of elucidating the zooarchaelogical records of seasonal resource procurement and seasonality in prehistoric shell middens. J Archaeol Sci 24:825-840

Selander RK, Smith MH, Yang SY, Johnson WE, Gentry JG (1971) Biochemical polymorphisms and systematics in the genus Peromyscus. I. Variation in the old-field mouse (Peromyscus polionotus). Studies in Genetics VI, University of Texas Publ 7103:49-90

Sokal RR, Rohlf FJ (1995) Biometry. WH Freeman, New York

Woodburn KD (1961) Survival and growth of laboratoryreared northern clams (Mercenaria mercenaria) and hybrids $(M$. mercenaria $\times M$. campechiensis) in Florida waters. Proc Natl Shellfish Assoc 52:31-36

Submitted: August 18, 2008; Accepted: December 23, 2008 Proofs received from author(s): February 2, 2009 